\title{
A Review about the Sustainability of Pit Lakes as a Rehabilitation Factor after Mine Closure ${ }^{\dagger}$
}

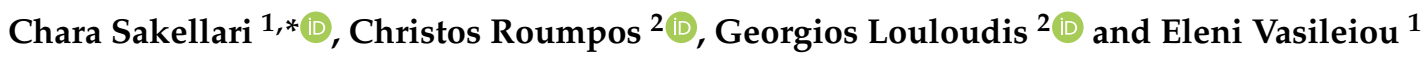 \\ 1 School of Mining and Metallurgical Engineering, Department of Geo-Sciences, National Technical University \\ of Athens, Heroon Polytechneiou 9, 15780 Athens, Greece; elvas@metal.ntua.gr \\ 2 Public Power Corporation of Greece, Department of Mining Engineering, 10432 Athens, Greece; \\ c.roumpos@dei.gr (C.R.); g.louloudis@dei.gr (G.L.) \\ * Correspondence: xarasak@gmail.com; Tel.: +30-2107722095 \\ + Presented at International Conference on Raw Materials and Circular Economy, Athens, Greece, \\ 5-9 September 2021.
}

check for

updates

Citation: Sakellari, C.; Roumpos, C.; Louloudis, G.; Vasileiou, E. A Review about the Sustainability of Pit Lakes as a Rehabilitation Factor after Mine Closure. Mater. Proc. 2021, 5, 52. https://doi.org/10.3390/ materproc2021005052

Academic Editor: Evangelos Tzamos

Published: 2 December 2021

Publisher's Note: MDPI stays neutral with regard to jurisdictional claims in published maps and institutional affiliations.

Copyright: (c) 2021 by the authors. Licensee MDPI, Basel, Switzerland. This article is an open access article distributed under the terms and conditions of the Creative Commons Attribution (CC BY) license (https:// creativecommons.org/licenses/by/ $4.0 /)$.
Abstract: At the end of surface mining activities, the remnant voids are of great concern regarding rehabilitating the final open pits. The investigation of the sustainability of pit lakes in post-mining regions constitutes a challenging research problem. This paper aims to highlight the effectiveness of pit lakes as a rehabilitation factor. In this framework, several cases worldwide and in Greece were examined in detail and evaluated. The results indicate that mine pit lakes must be evaluated as dynamic systems, natural or artificial, which demand rational mine water management to ensure their sustainability. Specifically in Greece, it is of great importance during the transition to the post-lignite era.

Keywords: mine water management; mine phase-out; mine lakes; post-lignite era

\section{Introduction}

Mine planning and mine closure demand a strong consideration of water quality during the mining life cycle. Pit lakes are permanent features created in mostly large and deep voids that remain after a mine's closure. Their size and depth vary depending on the surface excavations [1]. They are considered small catchments with unique characteristics. The final depth of the pit lake is strongly associated with the water balance between inflows and outflows, and its time stabilization may range from a few years to many decades.

Pit lakes are a common post-closure proposed solution at mine sites where open pits are filled with groundwater and surface runoff. However, the large volume of pit lakes and their potential role in water management make them a central theme of closure planning. Given the implications for environmental protection, regulatory compliance, and the potential long-term environmental liability of pit lakes, considerable attention has been given to their management, characterization, and remediation. Lakes are usually formed by the flooding of open pits or by filling naturally, and hydrological and hydrogeological factors drive surface and groundwater inflows. Therefore, pit lakes are a crucial factor for sustainable mine closure and rehabilitation. One of the most crucial environmental issues after creating pit lakes is related to their water quality. The role of geological, hydrogeological, hydrological, and geochemical conditions in the mining areas as principal components for predicting the water chemistry and the sustainability of pit lakes needs to be analyzed in correlation with climate changes.

\section{Materials and Methods}

In this study, several cases from South Africa (Coalfields), Western Australia (Collie Coal Basin), Central Germany (lignite mining district), and Greece (ferro-nickel mining area, magnesite mine, and lignite mining areas) are investigated and evaluated. The advantages 
and the risks of the pit lakes as environmental and aesthetic solutions are analyzed for each case study, and the crucial factors of their formation and preservation are pointed out.

A typical conceptual model of mining lakes is described in Figure 1, highlighting the relationship between parameters and geochemical processes concerning pit lakes' operation and water quality.
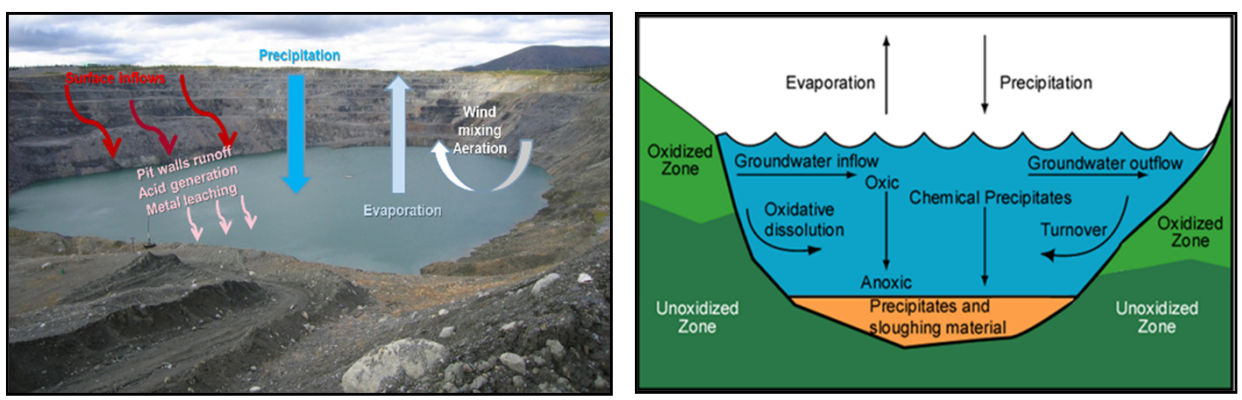

Figure 1. Modified conceptual model of pit lakes [1].

The principal factors driving the water balance of the pit lakes are (a) precipitation, (b) runoff, (c) groundwater, and (d) inflow from other mine workings. The significant losses from the pit lakes are due to evaporation and surficial discharge of water.

\section{Results and Discussion}

\subsection{Pit Lakes in South Africa}

After the closure of the three representative South African coalfields-Waterberg, Witbank/Mpumalanga and Natal—-the Mafutha, Kriel, and Rooikop pit lakes were created, respectively [2]. The three pit lakes are presented in Figure 2, and their characteristics are described in Table 1.

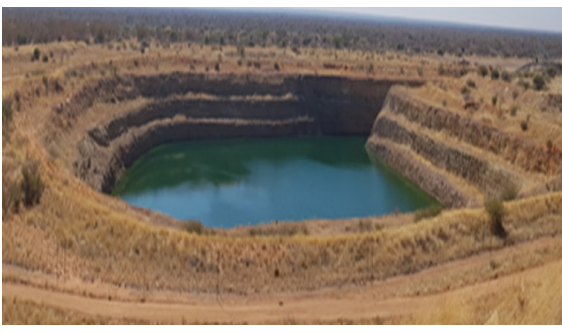

(a)

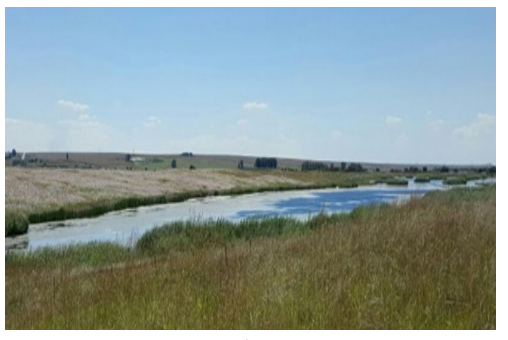

(b)

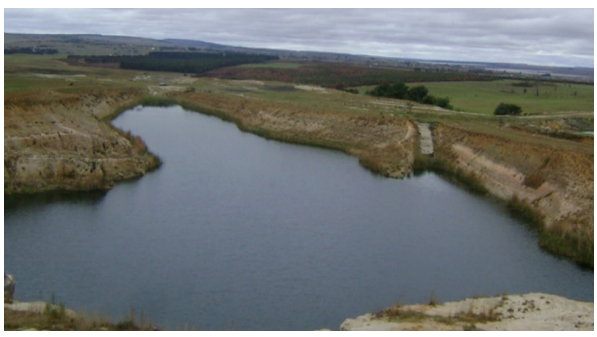

(c)

Figure 2. (a) Mafutha pit lake (September 2018); (b) Kriel pit lake 4: Ramp 44 North (March 2017); and (c) Rooikop pit lake (November 2017) [2].

Table 1. Pit lakes' characteristics.

\begin{tabular}{cccc}
\hline Characteristics & Mafutha & Kriel & Rooikop \\
\hline Coalfield & Waterberg & Witbank/Mpumalanga & Natal \\
\hline Nature of pit lake & Deep single open pit & Multiple pits hydraulically connected & $\begin{array}{c}\text { Single lake connected to } \\
\text { underground workings }\end{array}$ \\
Mining method & Bulk sample & Open cast roll over method & Underground bord and pillar \\
Age (years) & 8 & 13 & 12 \\
Surface area $\left(\mathrm{m}^{2}\right)$ & 26,600 & 272,530 & 17,100 \\
Pit lake volume $\left(\mathrm{m}^{3}\right)$ & 505,800 & 797,071 & 86,681 \\
Depth $(\mathrm{m})$ & 70 & 7 & 10 \\
pH & 8.4 & 8.4 & 7.9 \\
\hline
\end{tabular}

The Mafutha pit lake was created in a single deep void and maintains equilibrium (inflows and outflows) with minor seasonal variations in pit lake levels. The Kriel site is 
composed of several hydraulically connected open voids due to the extended excavations of the coal mine and highly permeable backfilled material. Inflow in the Kriel pit lake exceeds evaporation and groundwater outflow, resulting in the periodic surface outflow. The Rooikop pit lake has a positive water balance, and outflow occurs in the subsurface along the coal seam. It should be mentioned that, in South Africa, according to the climatic conditions, evaporation exceeds precipitation by a factor of 2 to 3 , and therefore it is the main factor for the water losses.

Taking all the above together, the morphology of the voids is a critical factor in respect to the water balance and water quality of a pit lake and a crucial one in determining their environmental sustainability [2]. As a result, pit lakes are a proven sustainable pit closure option for the rehabilitation of South African coal mines.

\subsection{Pit Lakes in Western Australia}

In Western Australia and specifically in the Collie Coal Basin, more than 100 coal mining fields operated until 1997. Thirteen (13) pit lakes have been created with various water qualities and extents of rehabilitation [3]. All the pit lakes are characterized by moderate acid and metalliferous drainage (AMD) due to the oxidation of sulfides in the region's geological environment [4].

Concerning the mine closure in the basin, a master plan was developed for a "closed catchment lake", including a permanent diversion channel of Collie River South Branch (CRSB) around the most considerable mine void. This decision was based on the fact that naturally, it would take 100 years for the mine void to be filled. Thus, river water was diverted to the mine void during high flow periods (over the winters between 2002 and 2008) [3]. In 2004, the created pit lake was named Lake Kepwari (total volume $32 \times 10^{6} \mathrm{~m}^{3}$, maximum depth $65 \mathrm{~m}$, perimeter of $5.4 \mathrm{~km}$, and surface area of $1.9 \mathrm{~km}^{2}$ ) [3]. During the following years of the pit lake's operation, the decrease of river inflows caused a deterioration of the water quality $(\mathrm{pH}=4$, elevated concentrations of potentially toxic elements (PTEs)). However, the water quality was improved in the following years since permanent inflows were ensured by rivers flowing into the lake $[3,5,6]$.

The town of Collie is strongly related to the mining industry and power generation, though tourism is becoming an essential driver of a more diversified economy. The transformation of Lake Kepwari into a recreation hub for water sports is expected to attract an influx of tourists (Figure 3). Early estimates anticipate that after three years, Lake Kepwari should attract up to 22,000 overnight stays and 37,000 day trip visitors annually [3].

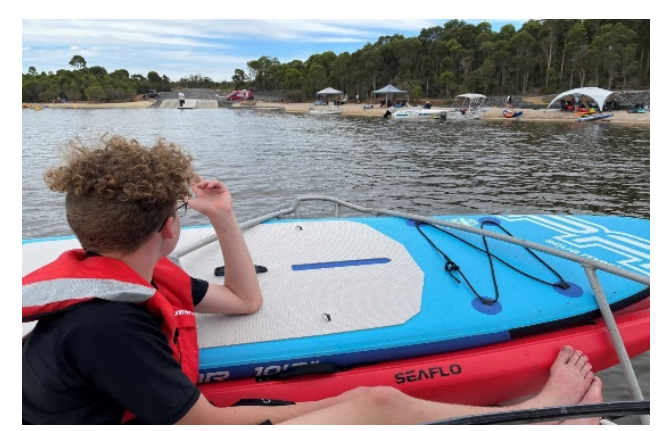

(a)

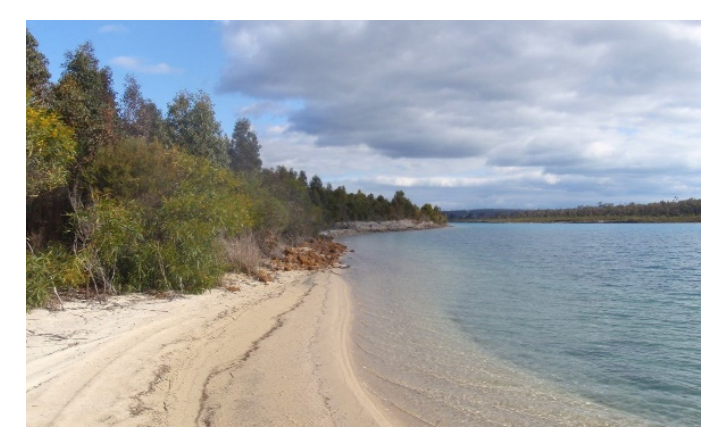

(b)

Figure 3. (a) Lake Kepwari in 2009; (b) locals and tourists recreating at Lake Kepwari soon after it opened in summer 2021 [3].

It should be pointed out that other created pit lakes in the Collie Coal Basin, without the planning of additional inflows from nearby rivers or other supplies, are acidic and are usually used to manage the water runoff from the mine site [6]. 


\subsection{Pit Lakes in Central Germany}

About 140 pit lakes in Central Germany were created artificially in the permanent voids of lignite mining, consisting of essential parts of the post-mining landscape in the Central German lignite mining district. Based on monitoring measurements concerning the water quality of the pit lakes, it was concluded that these pit lakes are at a low risk of eutrophication and contamination from industrial pollutants. However, in some cases, the intrusion of naturally saline groundwater from deep groundwater was recorded, while in other cases, elevated concentrations of sodium chloride and acidification were observed [7].

The Mulde reservoir pit lake was the first one in the Central German lignite mining district to be filled with river water in 1957 and 1976 (max depth of $26 \mathrm{~m}$ and total volume of $118 \times 10^{6} \mathrm{~m}^{3}$ ). At the beginning of the 1990s, many open-cast lignite mines were closed, and therefore many voids remained. In order to achieve fast filling of the voids with water, river water or mine water was used. The fast filling of the pit lakes was selected because, in this way, both stabilizations of the void pit walls and limitation or prevention of the lake acidification were achieved. Four rivers have been diverted to fill eleven pit lakes: River Saale for Lake Runstaedt and Lake Geiseltal; River Weiße Elster for Lake Wallendorf, Lake Rassnitz, and Lake Werbelin; River Mulde for the Muldereservoir, Lake Goitsche, Lake Seelhausen, Lake Gremmin, and Lake Grobern; and River Selke for Lake Concordia.

Initially, in Central Germany, about $50 \%$ of the pit lakes were acidic or had the potential to turn acidic, and the other $50 \%$ never had acid water due to the local geological environment. The first percentage has declined significantly, mainly due to the pit lakes being filled with river water or water from the dewatering of the mines. Acidic pit lakes already have elevated Fe concentrations at low $\mathrm{pH}$ values and usually accept recharge from groundwater enriched in Fe [7].

The neutralization of these pit lakes could be achieved from a few years up to some decades (Lake Nenkersdorf became neutral within five years, while Lake Bergwitz required about 25 years after its filling with groundwater and local runoff). In some cases, further necessary mechanisms of neutralization were evaluated, such as (i) natural washout and flushing of the lakes and the underground, (ii) the inflow of bicarbonate with naturally neutral groundwater, and (iii) microbial sulphate reduction. It was also observed that river water inflow contributed to the neutralization of the lake water. Therefore, since mid-2016, river water has been diverted to the pit lake regularly in addition to mine water [7].

Pit lakes in Central Germany fulfil modern environmental standards and positively affect the socio-economic development of the regions around them. Some of these pit lakes became part of the protected areas for nature conservation (e.g., Lake Rassnitz, Lake Paupitzsch, Lake Gremmin), while others are used for fish breeding (e.g., the Mulde reservoir). A few lakes are used for water management purposes, mainly flood protection (e.g., Lake Borna, Lake Zwenkau after reaching the planned water level).

\subsection{Pit Lakes in Greece}

In Greece, the created pit lakes are limited and include those (a) in central Euboea (ferro-nickel mining operated until 1991), (b) in Northern Euboea (magnesite mine in Mantoudi operated until 1980), (c) in Southern Euboea (lignite mine in Aliveri operated until 1990), (d) in Peloponnese (lignite mine of Kyparissia and Marathousa in Megalopolis mining area operated until 2009), and (e) in Western Macedonia (Amynteon mine operated until 2020). All Greek pit lakes are characterized by good quality [8].

In the Megalopolis lignite center, in the remnant mine void of the Kyparissia lignite field (Figure 4a), a large pit lake has been formed, presenting a surface of $0.8 \mathrm{~km}^{2}$ and a depth of $30 \mathrm{~m}$ with a total water volume of approximately $20 \times 10^{6} \mathrm{~m}^{3}$. There is a need for constant monitoring of the pit lake, as it is directly hydraulically connected with a karstic aquifer with a high capacity and good qualitative characteristics. In the Megalopolis lignite center, the second pit lake is Marathoussa, formed in the deepest part of the mine excavations, mainly by rainfall runoff accumulation, with no hydraulic connection with 
other aquifer systems. The maximum depth of the lake water is approximately $15 \mathrm{~m}$, with a surface of $0.25 \mathrm{~km}^{2}$ and with limited potential development.

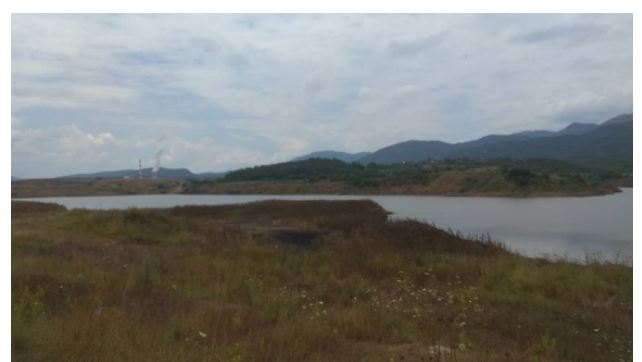

(a)

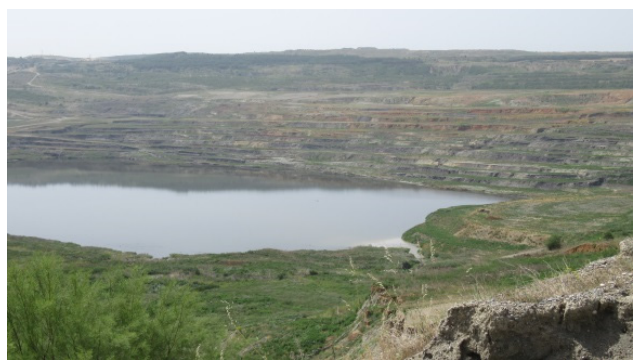

(b)

Figure 4. (a) Kyparissia pit lake and (b) Amynteon pit lake.

In the Amynteon Mine, a pit lake was created (Figure 4b). It covers an area of $0.40 \mathrm{~km}^{2}$, and it is recharged mainly by precipitation, the surface runoff of the pit walls, and the recharge of the groundwater. The rate of surface water rise was estimated to exceed $10 \mathrm{~m} /$ year in the early stages of Amynteon Lake's development [9].

In the Aliveri area, two pit lakes were created in the final voids (Figure 5). The total water volume of the big lake was estimated at approximately $450,000-500,000 \mathrm{~m}^{3}$ and its depth at approximately $50 \mathrm{~m}[10,11]$. The lake was created after the completion of the surface lignite exploitation. The creation of remnant lakes seems to be an aesthetically acceptable solution. However, subsidence appeared at the north slope, making this area not accessible and the pit lake not stable and functional (Figure 4) [11]. The lake's water level tends to increase with time, as the main recharge comes from the rainfall, which is high in this area $(900 \mathrm{~mm} /$ year).

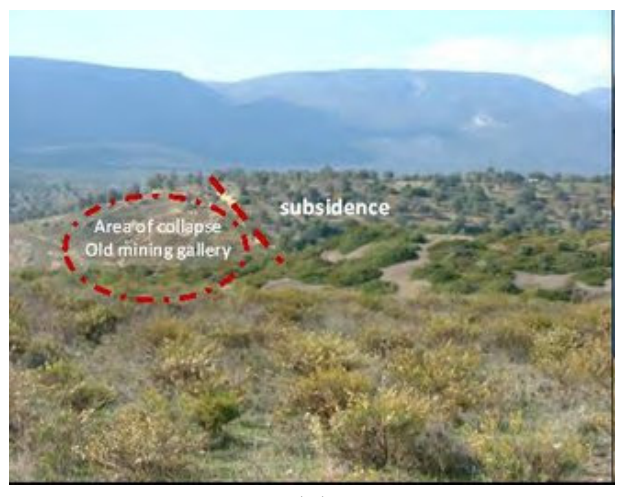

(a)

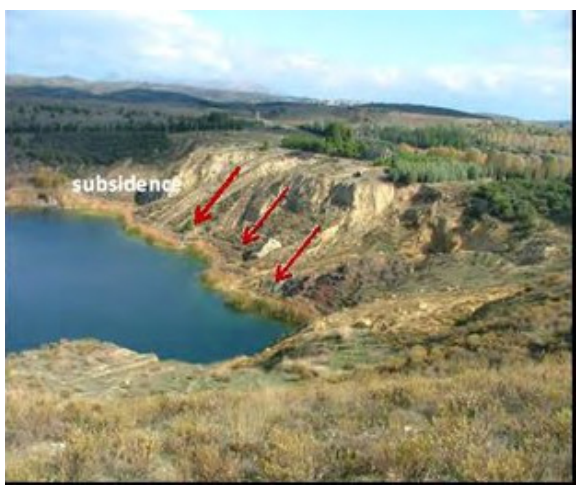

(b)

Figure 5. Aliveri pit lake: (a) SW lake's slope, where failures were observed and (b) west area where subsidence is depicted [11].

\section{Conclusions}

Based on the investigated case studies of mine pit lakes, rational environmental management ensures the mining exploitation plans and the mine closure. The sustainability of pit lakes as rehabilitation factors demands rational mine water management and technical support studies to be designed correctly. In most countries with surface mining fields, pit lakes have been adapted as a sustainable closure option.

In conclusion, mine pit lakes must be considered as dynamic systems, natural or artificial. Therefore, the formation and maintenance of pit lakes as a rehabilitation factor is globally qualified and emphasized as an efficient environmental solution in order to minimize the long term impacts of surface mining activities, specifically in Greece. Furthermore, it is of great importance during the transition to the post-lignite era. 
The crucial issue of every pit lake's sustainability is to distinguish the specific conditions that influence the lake. The conditions that can strongly influence the pit's water quality include hydrogeology, hydrology, geochemistry, limnology, mine planning, pit backfilling, input water quality, and flow rates.

Author Contributions: Conceptualization, C.S., C.R., G.L. and E.V.; methodology, C.S., C.R., G.L. and E.V.; software, C.S., C.R., G.L. and E.V.; validation, C.S., C.R., G.L. and E.V.; formal analysis, C.S., C.R., G.L. and E.V.; investigation, C.S., C.R., G.L. and E.V.; resources, C.S., C.R., G.L. and E.V.; data curation, C.S., C.R., G.L. and E.V.; writing-original draft preparation, C.S. and E.V.; writing-review and editing, C.S., C.R., G.L. and E.V.; visualization, C.S. and E.V.; supervision, C.S., C.R., G.L. and E.V.; project administration, C.S., C.R., G.L. and E.V. All authors have read and agreed to the published version of the manuscript.

Funding: This research received no external funding.

Institutional Review Board Statement: Not applicable.

Informed Consent Statement: Not applicable.

Data Availability Statement: The data presented in this study are available on request from the corresponding author.

Conflicts of Interest: The authors declare no conflict of interest.

\section{References}

1. Vandenberg, J. Use of water quality models for design and evaluation of pit lakes. In Mine Pit Lakes: Closure and Management; McCullough, C.D., Ed.; Australian Centre for Geomechanics: Perth, Australia, 2011; pp. 63-80.

2. Johnstone, A. Are Pit lakes an Environmentally Sustainable Closure Option for South African Mines? In Proceedings of the IMWA 2019 Conference: "Mine Water: Technological and Ecological Challenges", Perm, Russia, 15-19 July 2019; Volume 7, pp. 469-476.

3. McCullough, C.; Evans, E. Behind Western Australia's First Successful Pit Lake Closure: Lake Kepwari. Available online: https:/ / www.ausimm.com/bulletin/bulletin-articles/behind-western-australias-first-successful-pit-lake-closure-lakekepwari/ (accessed on 10 May 2021).

4. McCullough, C.D.; Lund, M.A.; Zhao, L.Y.L. Mine Voids Management Strategy (I): Pit lake resources of the Collie Basin; Mine Water and Environment Research/Centre for Ecosystem Management Report No. 2009-14, Unpublished Report to Department of Water; Government of Western Australia; Edith Cowan University: Perth, Australia, 2010; p. 229.

5. McCullough, C.D.; Kumar, R.N.; Lund, M.A.; Newport, M.; Ballot, E.; Short, D. Riverine breach and subsequent decant of an acidic pit lake: Evaluating the effects of riverine flow-through on lake stratification and chemistry. In Proceedings of the International Mine Water Conference, Bunbury (IMWA 2012), Western Australia, 30 September-4 October 2012; pp. 533-539.

6. McCullough, C.D.; Schultze, M.; Vandenberg, J. Realizing beneficial end uses from abandoned pit lakes. Minerals 2020, 10, 133. [CrossRef]

7. Schultze, M.; Jolas, P.; Weber, L. Filling Remediation and Management of Pit Lakes by Using Mine Water-An Update. In Proceedings of the 12th International Conference on Mine Closure, Leipzig, Germany, 3-7 September 2018.

8. Dimitrakopoulos, D.; Vasileiou, E.; Stathopoulos, N.; Dimitrakopoulou, S. Estimation of the qualitative characteristics of post mining lakes in different lignite fields in Greece. In Mining Meets Water - Conflicts and Solutions (IMWA 2016); Drebenstedt, C., Paul, M., Eds.; TU Bergakademie Freiberg: Leipzig, Germany, 2016; pp. 219-225. ISBN 978-1-5108-2714-1.

9. Louloudis, G.; Kasfikis, G.; Mertiri, E. Spatiotemporal Forecasting of Amynteon Pit Lake; Technical Report; PPC SA, Sector of Hydrogeological Studies: Athens, Greece, 2020; Unpublished study. (In Greek)

10. Dimitrakopoulos, D.; Koumantakis, I.; Vasileiou, E. Water management after the closure of underground lignite mine in Aliveri, Greece. In Proceedings of the International Multidisciplinary Scientific GeoConference:Surveying Geology \& Mining Ecology Management (SGEM 2009), Sofia, Bulgaria, 14-19 June 2009; Volume 1, pp. 309-316.

11. Vasileiou, E.; Stathopoulos, N.; Stefouli, M.; Charou, E.; Perrakis, A. Evaluating the Environmental Impacts after the Closure of Mining Activities Using Remote Sensing Methods-the Case Study of Aliveri Mine Area. In Proceedings of the Annual Conference of International Mine Water Association (IMWAQ 2012), Bunbury, Australia, 30 September-4 October 2012; pp. 755-763. 